\title{
STARTEGI IMPLEMENTASI KEBIJAKAN PENANGANAN COVID 19 UNTUK KETAHANAN NASIONAL BERBASIS COMMUNITY DEVELOPMENT (KONSEP PENTAHELIX) DI PROPINSI MALUKU UTARA
}

\author{
Ali Ibrahim dan Henny Saptatia Drajati Nugrahani \\ Universtas Indonesia, Depok Jawa Barat, Indonesia \\ Email: ibrahimcaptali@gmail.com dan henny.saptatia@ui.ac.id
}

\section{Abstract:}

The COVID-19 pandemic that hit almost all countries in the world has not only an impact on health, but also all the joints of human life. Similarly, in Indonesia, with various limitations that exist. The government together with all components of the nation are working together to make effective rapid movements in the handling of this pandemic so as not to be prolonged. The purpose of this study is to find out the strategy of implementing covid-19 handling policy for national resilience based on pentahelix concept in north maluku province. Methods used in this study. The method used in writing this paper is literature review of various journals, reports, legislation or policies and then summarize the current conditions of understanding of a policy topic in handling Covid 19. The results of this study show that the implementation of Community Development as an effort to implement policies for national resilience as a result of the covid 19 outbreak conducted in an integrated manner will result in adaptation capacity, among others: cooperation, participation of all elements of society, the principle of mutual care, the use of technology that suits the needs of the community, and the ability to mobilize collective resources in group members.

Keywords: implementation of handling covid-19; national resilience; pentahelix concept

\section{Abstrak}

Pandemi COVID-19 yang melanda hampir seluruh negara di dunia ini tidak hanya berdampak pada kesehatan, tetapi juga semua sendi kehidupan manusia. Begitu pula di Indonesia, dengan berbagai keterbatasan yang ada. Pemerintah bersama segenap komponen bangsa bahu-membahu berupaya melakukan gerak cepat yang efektif dalam penanganan pandemi ini agar tidak berkepanjangan. Tujuan dari penelitian ini untuk mengetahui strategi implementasi kebijakan penanganan covid-19 untuk ketahanan nasional yang berbasis konsep pentahelix di provinsi maluku utara. Metode yang digunakan dalam penelitian ini. Metode yang digunakan dalam penulisan paper ini adalah literature review dari berbagai jurnal, laporan, perundangan atau kebijakan kemudian meringkas kondisi pemahaman terkini tentang suatu topik Kebijakan dalam penanganan Covid 19. Hasil dari penelian ini menunjukan bahwa Pelaksanaaan Community Development sebagai upaya implementasi kebijakan untuk ketahanan nasional sebagai dampak wabah covid 19 yang dilakukan secara terintegrasi ini akan menghasilkan kapasitas adaptasi, antara 
lain berupa: kerja sama, partisipasi semua elemen masyarakat, prinsip saling menjaga, pemanfaatan teknologi yang sesuai kebutuhan masyarakat, dan kemampuan memobilisasi sumber daya kolektif dalam anggota kelompok.

Kata kunci: implementasi penanganan covid-19; ketahanan nasional; konsep pentahelix

Coresponden Author

Email: ibrahimcaptali@gmail.com Artikel dengan akses terbuka dibawah lisensi

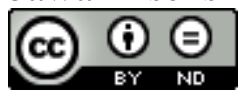

\section{Pendahuluan}

Pandemi COVID-19 yang melanda hampir seluruh negara di dunia ini tidak hanya berdampak pada kesehatan, tetapi juga semua sendi kehidupan manusia. Begitu pula di Indonesia, dengan berbagai keterbatasan yang ada. Pemerintah bersama segenap komponen bangsa bahu-membahu berupaya melakukan gerak cepat yang efektif dalam penanganan pandemi ini agar tidak berkepanjangan.

Pandemi Covid-19 yang melanda seluruh penduduk bumi pada tahun 2020 merupakan sebuah tragedi kemanusiaan yang mungkin belum pernah terpikirkan akan terjadi oleh umat manusia. Bill Gates mengatakan pada tahun 2015 dalam sebuah wawancara di program acara TED-Talks sudah memprediksi akan terjadi wabah karena virus dan sangat menular yang mampu membunuh lebih dari 10 juta orang. Keyakinan Bill Gates tersebut 2 tahun kemudian ditulis dalam laman resmi yayasan Bill And Mellinda Gates Foundation dan disalin juga oleh Business Insider dalam rangka mengisi acara Munich Security Conference tanggal 17 Februari 2017 yang intinya adalah bahwa akan ada sejenis terorisme baru yang dapat melenyapkan 30 juta orang dalam waktu kurang dari setahun dan ketika itu terjadi sayangnya dunia tidak siap (Gates, 2017).

Pendapat Bill Gates tersebut diulangi lagi pada tahun 2018 dalam acara diskusi ilmiah yang digagas oleh Massachusetts Medical Society bekerjasama dengan New England Journal of Medicine (NEJM) tanggal 23 April 2018. Pada acara tersebut Bill Gates yang tampil sebagai pembicara utama dengan makalah berjudul Epidemics Going Viral: Innovation Vs Nature kembali mengingatkan kemungkinan terjadinya kembali wabah di era modern yang mirip dengan tragedi virus Spanyol tahun 1918 dimana telah membunuh 50 juta orang lebih pada saat itu (Eifert, Banerjee, Jusys, \& Zeis, 2018).

Penyebaran Virus Corona Covid 19 di berbagai negara sebagaimana dapat dilihat di berbagai media baik cetak maupun elektronik menyebabkan timbulnya keresahan dan kekhawatiran bagi masyarakat disebabkan karena potensinya yang telah menjadi pandemi. Seperti yang kita ketahui bahwa COVID-19 sangat menular. Terjadinya kekhawatiran dari masyarakat merupakan hal yang wajar jika bencana tersebut terjadi dan keadaan ini merupakan respon yang sangat manusiawi pada diri manusia yangmana mereka menginginkan keselamatan dan kesehatan ketika sebuah keadaan terjadi dan mengancam seperti pandemi yang dialami saat ini. Kondisi ini juga melanda seluruh 
wilayah di Indonesia, tidak terkecuali Provinsi Maluku Utara. Oleh sebab itu, Pemprov Maluku Utara telah berusaha maksimal menangani wabah COVID-19. Pola hidup masyarakat di Maluku Utara sebagaimana di wilayah lain pun berupaya menangani kejadian pandemi ini dengan berbasiskan kearifan lokal sehingga dapat berperan dalam pencegahan kasus COVID-19.

Polemik mengenai ada tidaknya Covid-19 di Indonesia akhirnya terjawab. Pemerintah mengumumkan dua pasien pertama di Indonesia yang dinyatakan positif Covid-19 pada 2 Maret 2020 dan bertambah menjadi 19 orang (Rudi Natamiharja, 2020). Menurut data Johns Hopkins CSSE, jumlah orang yang terinfeksi COVID-19 di seluruh dunia mencapai 118.745 kasus, penderita paling banyak berada di China, pusat penyebaran virus, dengan 80.954 kasus (gisanddata. maps.arcgis.com, 11 Maret 2020). Pemerintah Indonesia pun sudah menetapkan status bencana nasional untuk Covid-19 yang tercantum dalam Keputusan Presiden Nomor 12 Tahun 2020 tentang Penetapan Bencana Nonalam Penyebaran Covid-19 Sebagai Bencana Nasiona Undang-Undang Nomor 24 Tahun 2007 tentang Penanggulangan Bencana membagi bencana dari bencana alam, nonalam dan sosial. Bencana nonalam adalah bencana yang diakibatkan oleh peristiwa atau rangkaian peristiwa nonalam yang antara lain berupa gagal teknologi, gagal modernisasi, epidemi, dan wabah penyakit. Dalam hal ini, Covid-19 termasuk bencana nonalam yang sudah berada di tingkat pandemi sesuai dengan pernyataan Badan Kesehatan Dunia (WHO).

Terlihat bahwa, pengaruh covid 19 terhadap ekonomi global telah berdampak luas terhadap ekonomi dalam negeri, peristiwa yang mempengaruhi sektor publik yang mempengaruhi kehidupan manusia antara lain sektor pendidikan, pariwisata, perdagangan, industri dan investasi. Kensenjangan dan kesejahteraan yang terjadi di daerah merupakan dampak yang nyata dari Covid 19 dari sisi ekonomi, rendahnya daya beli masyarakat, pembatasan tenaga kerja dan rendahnya proyek pembangunan infrastruktur didaerah menjadi ancaman terhadap ketersedian lapangan pekerjaan dan kecilnya pendapatan bagi masyarakat kondisi inilah yang dapat menjadi akar permasalahan timbulnya masalah kemiskinan.

Dalam perkembangannya akhir-akhir ini perekonomian khususnya dalam memasuki akhir dari kuartal I di tahun 2020 telah terjadi fenomena yang mengerikan yang dirasakan oleh seluruh manusia di dunia. Menurut (Liu et al., 2020) mengatakan International Monetary Fund dan World Bank organisasi berskala internasional bidang keuangan telah membuat prediksi bahwa hingga di akhir kuartal I di tahun 2020 ekonomi global akan memasuki resesi yang mana akan terkoreksi sangat tajam. Pertumbuhan ekonomi global dapat merosot ke negatif 2,8\% atau dengan kata lain terseret hingga 6\% dari pertumbuhan ekonomi global di periode sebelumnya. Pada sisi lain menurut (Carrillo-Larco \& Castillo-Cara, 2020) disebutkan padahal, kedua lembaga tersebut sebelumnya telah memproyeksi ekonomi global akan tumbuh pada persentase pertumbuhan sebesar 3\%di akhir kuartal I tahun 2020.

Dalam dokumen resmi siaran pers Kementerian Keuangan RI pada tanggal 20 Mei 2020 menyebutkan bahwa negara mengalami tekanan pelemahan pendapatan sebagai 
dampak perlambatan ekonomi karena pandemik Covid-19. Realisasi pendapatan sampai akhir bulan April 2020 baru mencapai 31,21 \% dari target APBN atau berjumlah Rp 549,51 triliun. Rincian pendapatan ini berasal dari penerimaan pajak sebesar Rp 434,33 triliun, dari Penerimaan Negara Bukan Pajak (PNBP) mencapai Rp 114,50 triliun dan sisanya dari realisasi hibah sebesar Rp 0,67 triliun (Suharsono, 2020).

Saat ini Pemerintah pusat telah mengimplemanetasikan berbagai program ataupun kegiatan dalam upaya penanganan dampak Covid 19 serta membuat kebijakankebijakan pendukung, yang mana dalam program ekonomi prioritas telah memformulasikan pada Rencana Kerja Pemerintah (RKP) tahun 2020. Dua program prioritas yang dikeluarkan yakni program ekuitas infrastruktur, wilayah dan program pengembangan ekonomi bernilai tambah, industrialisasi dan ekspansi kesempatan kerja secara nasional dan global dengan saling terhubung. Kedua program tersebut akan sangat bermanfaat bagi sinergitas antara pemerintah, swasta dan masyarakat karena memiliki sejumlah kegiatan untuk meningkatkan ketahanan kepada komunitas yang sangat rentan dan beresiko, mempertahankan sektor UMKM dan ekonomi formal, memperbaiki akses layanan dasar yang berkualitas dan meningkatkan inklusi keuangan (Hastuti et al., 2020).

Dampak dari pandemi Covid-19 ini dapat menjadi ancaman bagi ketahanan nasional, yang bisa terbuka lebar dan penuh ataupun sarat dengan adanya kepentingan internasional dalam siklus ketergantungan ekonomi global. Hal tersebut akan menjadi ancaman yang serius bagi Indonesia terutama didaerah yang memiliki tingkat kerawanan sosial seperti propinsi Maluku Utara dan beberapa daerah lain di Indonesia yang memiliki keterbatasan informasi dan fasilitas pendukung ekonomi yang memadai. Data BPS propinsi Maluku Utara tahun 2020 berkaitan dengan ketenagakerjaan, tingkat penganguran terbuka di Maluku Utara tahun 2019 sebesar 4,97 \% mengalami peningkatan dari tahun sebelumnya. Apalagi dimasa pandemi Covid 19 berlangsung tentunnya akan terus mengalami peningkatan yang cukup memprihatinkan (Statistik, 2020).

Berdasarkan laporan data dari Gugus Tugas Percepatan dan Penanganan Covid-19 Maluku Utara (Malut) mengumumkan tambahan 147 kasus positif virus corona baru atau Covid-19 pada buan Juli 2020. Penambahan 147 pasien positif baru ini, menjadikan Maluku Utara berada di posisi keempat secara nasional jumlah kasus positif. Persebaran dari pasien yang terbanyak berasal dari Halmahera Timur, sebanyak 58 orang. Selanjutnya dari Halmahera Utara sejumlah 50 orang, Kota Ternate sejumlah 32 orang, dari Kota Tidore Kepulauan sejumlah 5 orang, dan 2 orang dari Kepulauan Sula. Tambahan itu membuat jumlah pasien positif Covid-19 di Maluku utara menjadi 875 kasus (Kompas.com).

Berdasarkan data kejadian-kejadian tersebut menyebabkan pihak pemerintah Provinsi Maluku Utara mencari cara untuk menekan serta mencegah penyebaran Covid19 melalui berbagai startegi yang diimplementasikan kedalam program kegiatan maupun kebijakan pendukungnya. Pelibatan peran seluruh komponen baik itu dari akademisi, bisnis, masyarakat, pemerintah dan media secara bersama berupaya untuk 
minimal dapat menekan angka kasus dan bisa mengganti tatanan lama serta menerapkan ke arah tatanan baru atau News Normal. Kecepatan dan ketepatan fungsi dari inplementasi kebijakan dan kolaborasi adalah upaya melakukan sinkronisasi program didaerah yang memiliki tingkat kerawanan sosial dengan aplikasi yang bersentuhan langsung dengan masalah, serta mendorong partisipasi publik untuk ikut berperan aktif, baik secara kelembagaan dan komunitas. Arah perencanaan dalam pembangunan partisipatif itu dimulai dengan membangun ide atau gagasan yang lahir dari bawah (bottom up), masyarakat sebagai subyek pembangunan lalu di dorong dalam partisipasi dan akselarasi kebijakan terhadap program pemerintah. bersamaan dengan itu, ruangruang kolaborasi perlu dibuka dan ditingkatkan lalu diberi penguatan pada aspek kelembagaan sehingga konektifitas antara pemerintah dan masyarakat terbangun secara mandiri dalam upaya mengeksekusi kebijakan.

\section{Metode Penelitian}

Metode yang digunakan dalam penulisan paper ini adalah literature review dari berbagai jurnal, laporan, perundangan atau kebijakan kemudian meringkas kondisi pemahaman terkini tentang suatu topik Kebijakan dalam penanganan Covid 19. Dasar pemikiran digunakannya metode ini adalah karena penulisan paper ini ingin mengetahui tentang fenomena yang ada dan dalam kondisi yang alamiah, bukan dalam kondisi terkendali, labolatoris atau eksperimen. Sesuai dengan topik yang menjadi fokus dalam paper ini yaitu gambaran deskriptif mengenai percepatan penanganan bencana Pandemi yang melibatkan masyarakat dan komunitas (Strategi Implemantasi Kebijakan Penanganan Covid 19 Untuk Ketahanan Nasional Berbasis Community Development (Konsep Pentahelix) di Propinsi Maluku Utara).

\section{Hasil dan Pembahasan}

\section{Kebijakan Regulasi dan Anggaran Penangulangan Covid 19}

Wabah pandemi COVID-19 memang telah memberikan dampak yang luar biasa bagi tatanan dan organisasi sosial masyarakat dunia, termasuk kita di Maluku Utara. Masyarakat membutuhkan bantuan agar memiliki daya tahan di tengah wabah pandemi ini. Oleh sebab itu, diperlukan adanya kebijakan pemerintah untuk memberi stimulus, berupa bantuan termasuk dengan penggunaan Dana Desa untuk membantu warga terdampak. Namun kemudian, muncul sejumlah masalah atas pengelolaan dana desa di beberapa desa di Maluku Utara. Untuk itu perlu dilakukan langkahlangkah didalam upaya mengimplementasikan bantuan yang akan disalurkan ke desa-desa melalui dana desa dengan:

a. Melakukan pemetaan terkait dengan masalah kebutuhan masyarakat, kodisi masyarakat terdampak

b. Perencanaaan serta pengawaasan program bantuan

c. Pembinaan serta edukasi terhadap masyarakat

Melalui Kebijakan pemerintah Pada 31 Maret 2020, Presiden RI menerbitkan Peraturan Pemerintah Pengganti UU No 1 Tahun 2020 (PERPPU 01/2020) tentang 
Kebijakan Keuangan Negara dan Stabilitas Sistem Keuangan untuk Penanganan Pandemi Corona Virus Disease 2019 (Covid-19) dan/atau dalam Rangka Menghadapi Ancaman yang Membahayakan Perekonomian Nasional dan/atau Stabilitas Sistem Keuangan. Total anggaran untuk ini adalah sebesar Rp 405,1 triliun. Dan Pada 3 April 2020, Presiden menerbitkan Peraturan Presiden (Perpres) No. 54 Tahun 2020 tentang Perubahan Postur Rincian dan APBN Tahun 2020. Perpres ini merupakan tindak lanjut dari Perppu No. 1 Tahun 2020. Anggaran dari beberapa kementerian dipotong sebesar Rp 97,42 triliun. Namun, beberapa Kementerian mengalami peningkatan anggaran, seperti Kementerian Pendidikan dan Kebudayaan sebesar dari Rp 36 triliun menjadi Rp 70 triliun; dan Kementerian Kesehatan dari Rp 57 triliun menjadi 76 triliun.

Penerbitan Keputusan Presiden (Keppres) No. 7 Tahun 2020 tentang Gugus Tugas Percepatan Penanganan Corona Virus Disease 2019 (Covid-19) pada 13 Maret 2020; dan Keppres No. 9 Tahun 2020 tentang Perubahan atas Keppres No. 7 Tahun 2020 pada 20 Maret 2020.

1. Bidang Kesehatan (senilai Rp 75 triliun

2. Bidang Sosial (senilai Rp 110 triliun)

3. Kebijakan Fiskal dan Insentif Pajak (senilai Rp 70,1 triliun)

4. Kebijakan Perdagangan Ekspor-Impor

5. Usaha Mikro, Kecil, dan Menengah (UMKM) senilai Rp 150 triliun

6. Pembatasan Sosial Berskala Besar (PSBB)

7. Bidang Hukum

8. Kebijakan/Fasilitas Lainnya

\section{a. Pentahelix}

Carayannis dan Campbell pada tahun 2012 telah mengajukan konsep Quintuple Helix yang bahkan berbeda sejak heliks keempat. Mereka satu suara dengan ahli lain sampai pada konsep Triple Helix (Akademis, Bisnis dan Pemerintah) saja. Dalam konsep yang diajukan oleh mereka memang tidak menggunakan istilah Penta Helix, namun menggunakan nama Konsep Quintuple Helix yang terdiri dari: 1) Akademisi; 2). Bisnis; 3) Pemerintah; 4) Media, industri dan kelompok kreatif, seni budaya, gaya hidup; dan 5) Lingkungan dan alam (Carayannis \& Campbell, 2010). 


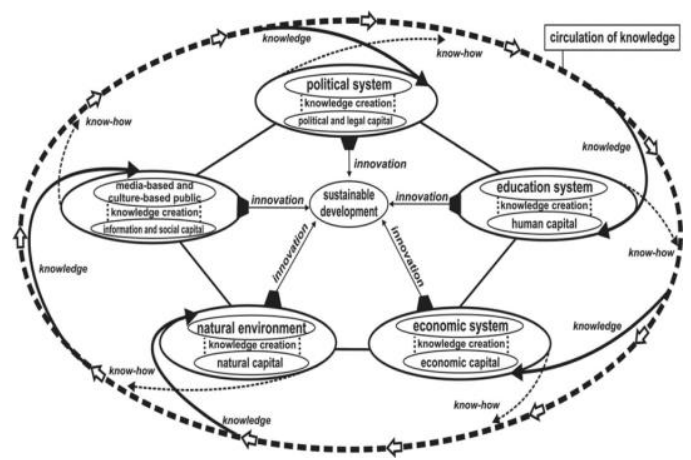

\section{Gambar 1 \\ Model Quintuple Helix Carayannis and Campbell (2012) \\ Sumber: Carayannis and Campbell (2012)}

Konsep berbeda diajukan oleh Igor Calzada pada tahun 2016 yang merumuskan konsep Penta Helix dalam terminologi yang diajukan sebagai "Multi-Stakeholders Interdependencies" dengan konteks tujuan pembangunan ekonomi dan sosial. Konsep tersebut memasukkan unsur lembaga non pemerintahan seperti LSM atau Non-Government Organization (NGO) sebagai heliks kelima. Sehingga konsep Penta Helix adalah interaksi dan kolaborasi dari komponen-komponen akademisi, dunia bisnis, pemerintah, komunitas masyarakat sipil dan lembaga swadaya masyarakat non-pemerintah (Calzada, 2016). Pendapat (Calzada, 2016) didukung oleh (Hendriyana, Putra, \& yan Sunarya, 2020) yang menawarkan komponen Penta Helix terdiri dari: 1) akademisi yang akan mendorong implementasi inovasi dan kewirausahaan; 2) pemerintah yang mendukung inovasi dalam investasi publik; 3) dunia bisnis atau swasta dalam hal pendanaan dan teknik komersialisasi produk; 4) dan 5) adalah lembaga non-pemerintah dan masyarakat sipil melalui partisipasi aktifnya dalam pembangunan sosial dan ekonomi (Halibas, Sibayan, \& Maata, 2017).

Di Indonesia, terminologi Penta Helix pertama kali diperkenalkan secara resmi oleh Menteri Pariwisata Arief Yahya dalam dokumen Peraturan Menteri (Permen) Pariwisata Nomor 14 Tahun 2016 Tentang Pedoman Destinasi Pariwisata Berkelanjutan. Konsep Penta Helix adalah media sehingga konsep Penta Helix khususnya di Indonesia merupakan interaksi dan kolaborasi dari kalangan akademisi di universitas, pelaku industri usaha (bisnis), pemerintah, komunitas masyarakat sipil dan media (Sudiana, Sule, Soemaryani, \& Yunizar, 2020). Dalam implementasi konsep pentahelix, dapat dilakukan dengan menggalang kekuatan untuk melawan corona virus itu yakni yang juga datang dari dalam diri masyarakat sendiri. Masyarakat lokal mempunyai kearifankearifan lokal. Mereka memiliki sumber daya dan spirit lokal. Ini yang mesti diberdayakan. Kesadaran masyarakat mesti diberdayakan karena sejatinya mereka mempunyai kesadaran. 


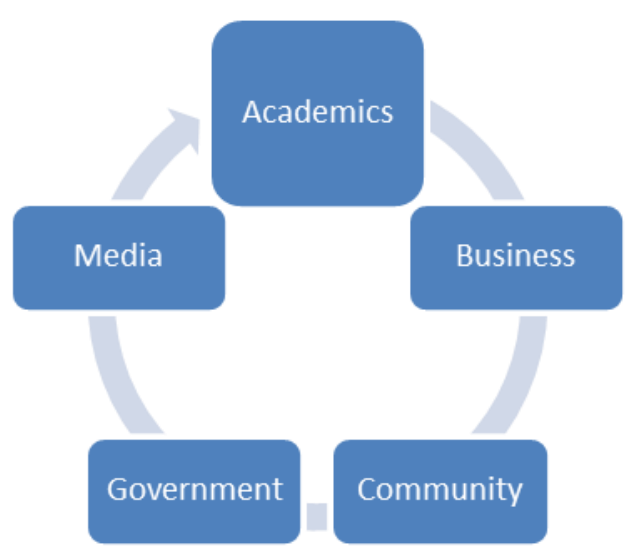

Gambar 2

Model Penta Helix Indonesia (ABGCM)

Sumber: Sudiana et. Al (2020). Gambar Diolah Penulis

Pentahelix sebagai persinggungan kesadaran bersama pemerintah dan masyarakat memungkinkan terlaksananya tekad ini, melindungi warga yang masih sehat agar tidak tertular penyakit dan semaksimal mungkin menyembuhkan yang telah sakit. Pendekatan berbasis komunitas ini penting untuk menggempur corona dari berbagai sisi. Sekaligus memberikan kejelasan rantai koordinasi dan kendali dalam gugus tugas percepatan penanganan Covid19 yang sudah dibentuk hingga di daerah.

Posisi Community Development menjadi penting untuk disorot mengingat paradigma pembangunan yang diberlakukan tersebut lebih bersifat bottom up ketimbang top down. Sehingga Community Development sebagai bagaian dari konsep pentahelix dapat masuk dalam dimensi sosial dari paradigma pembangunan berkelanjutan yang mencoba mengintegrasikan tiga dimensi: sosial, ekonomi dan lingkungan. Community Development sebagai kegiatan pengembangan masyarakat yang diarahkan untuk memperbesar akses masyarakat untuk mencapai kondisi sosial-ekonomi-budaya yang lebih baik apabila dibandingkan dengan sebelum adanya kegiatan pembangunan. Selain itu, posisi peran serta masyarakat melalui Community Development juga berperan positif dalam dimensi politik karena mendorong partisipasi, aksesibilitas dan kebebasan masyarakat yang juga menjadi prinsip dalam paradigma pembangunan inklusif berkelanjutan melalui kearifan lokal. lingkungan disekitarnya. Mereka hidup dalam berbagai ekosistem alami yang ada di Indonesia, dan telah lama hidup berdampingan dengan alam secara harmonis, sehingga mengenal berbagai cara memanfaatkan sumberdaya alam secara berkelanjutan. Kearifan lokal (Suhartini, 2009) merupakan warisan nenek moyang kita dalam tata nilai kehidupan yang menyatu dalam bentuk religi, budaya dan adat istiadat. Dalam perkembangannya masyarakat melakukan adaptasi terhadap lingkungannya dengan mengembangkan suatu kearifan yang 
berwujud pengetahuan atau ide, peralatan, dipadu dengan norma adat, nilai budaya, aktivitas mengelola lingkungan guna mencukupi kebutuhan hidupnya

Berdasarkan paradigma pembangunan berkelanjutan yang mana dapat diartikan sebagai pembangunan yang memenuhi kebutuhan masa kini tanpa mengurangi kemampuan generasi masa depan untuk memenuhi kebutuhannya, mempunyai 3 pilar utama (pertumbuhan ekonomi, pengentasan kemiskinan \& keberlanjutan) yang bersumber dari dua gagasan penting yaitu: (1) gagasan kebutuhan, khususnya kebutuhan esensial kaum miskin sedunia, yang harus diberi prioritas utama. (2) gagasan keterbatasan yang bersumber pada kondisi teknologi dan organisasi social masyarakat terhadap kemampuan lingkungan untuk memenuhi kebutuhan masa kini dan hari depan.

Peran Serta Masyarakat (PSM) adalah proses dimana individu, keluarga dan lembaga masyarakat termasuk swasta:

a. Mengambil tanggung jawab atas kesehatan diri, keluarga dan masyarakat.

b. Mengembangkan kemampuan untuk menyehatkan diri, keluarga dan masyarakat.

c. Menjadi pelaku perintis kesehatan dan pemimpin yang menggerakkan kegiatan masyarakat di bidang kesehatan berdasarkan atas kemandirian dan kebersamaan

Melalui Community Development dalam menangani masalah Covid-19 serta untuk mencapai tujuan pembangunan kesehatan maka Community Development tersebut dapat dijadikan sebagai salah satu pemacu dan semangat untuk dapat melakukan upaya yang lebih baik dalam penanganan permasalahan yang terkait dengan pemenuhan kebutuhan dasar manusia. Karena kesehatan bukan hanya masalah bagi permasalahan negara saja tetapi juga masyarakat, dan bahkan juga merupakan masalah dunia. Dilihat dari berbagai program dan kegiatan yang sudah dilaksanakan dan besarnya sumber dana yang telah dikeluarkan, kesehatan di Indonesia tetap masih menjadi permasalahan yang tidak mudah untuk diatasi. Hal tersebut terjadi antara lain karena upaya penanggulangan masalah kesehatan merupakan upaya terpadu yang harus dilakukan oleh semua pihak termasuk juga masyarakat itu sendiri dengan komitmen yang kuat dari semua unsur pimpinan baik Pemerintah, organisasi masyarakat dan kelompok masyarakat.

\section{b. Implementasi Kebijakan Community Development berbasiskan kearifan lokal dalam penanganan Covid 19}

Secara formal, peran serta masyarakat dalam upaya PB itu diatur dalam Peraturan Kepala Badan Nasional Penanggulangan Bencana Nomor 11 Tahun 2014 tentang Peran Serta Masyarakat dalam Penyelenggaraan Penanggulangan Bencana (Perka BNPB No.11/2014). Peraturan ini merupakan mandat dari Pasal 26 Undang-Undang Nomor 24 Tahun 2007 tentang Penanggulangan Bencana (UU No. 24/2007), Pasal 2 Peraturan Pemerintah Nomor 21 Tahun 2008 tentang Penyelenggaraan Penanggulangan Bencana (PP No. 21/2007), dan Pasal 4 
Peraturan Pemerintah Nomor 22 Tahun 2008 tentang Pendanaan dan Pengelolaan Bantuan Bencana (PP No. 22/2008). Perka BNPB No.11/2014 ditetapkan oleh Kepala BNPB, Syamsul Maarif pada tanggal 16 Oktober 2014 di Jakarta.

Tujuan Perka BNPB No.11/2014 adalah untuk mendukung penguatan kegiatan Penanggulanagn Bencana (PB) dan kegiatan pendukung lainnya secara berdaya guna, berhasil guna, dan dapat dipertanggungjawabkan. Disini pengertian peran serta masyarakat adalah proses keterlibatan masyarakat dalam penyelenggaraan PB secara terencana, terpadu, terkoordinasi, dan menyeluruh dalam rangka memberikan perlindungan kepada masyarakat dari ancaman risiko dan dampak bencana.

Wabah dari Covid-19 ini harus terus diatasi dan distop penyebarannya, dengan memperhatikan situasi yang terjadi di Indonesia jika terus meningkat ataupun melonjak angka penyebaran virus maka tentunya akan mengancam dalam berbagai sektor. Sektor ekonomi contohnya akan mengalami krisis seperti masalah penurunan daya beli masyarakat. Penanganan dan pencegahan terus dilakukan oleh pemerintah berupa kebijakan, himbauan, maupun langkahlangkah yang kongkrit dan progesif didalam upayanya melawan virus corona. Selain itu tidak lupa diharapkan adanya partisipasi masyarakat pun turut aktif dalam melawan virus tersebut.

Berdasarkan teori modal sosial bahwa jika terjadi masalah besar di dalam masyarakat tentunya akan membutuhkan nilai-nilai sosial. Dapat diartikan bahwa, kelompok sosial akan membutuhkan suatu kerjasama seluruh dalam menyelesaikan masalah tersebut. Sehingga, modal sosial ini dapat dijadikan sebagai barang publik oleh pemerintah dipergunakan untuk jaringan horizontal yang dapat menjadi eksistensi dalam masyarakat. Modal sosial juga akan dapat memberikan arah bagi masyarakat untuk secara suka rela mau berkonstribusi dalam menyelesaikan masalah yang ada. Robert Putnam mengatakan, bahwa modal sosial dapat menjadi penyegar dalam kehidupan sosial yang secara pokok ataupun subtansinya memiliki kepercayaan untuk bertindak secara bersama dalam mewujudkan suatu tujuan bersama

Departemen Kesehatan merumuskan visinya, sebagai "Masyarakat yang mandiri untuk hidup sehat" dan misinya yaitu "Membuat masyarakat sehat", dengan strategi, yaitu menggerakkan dan memberdayakan masyarakat untuk hidup sehat, meningkatkan akses masyarakat terhadap pelayanan yang berkualitas, meningkatkan sistem surveilans, monitoring, dan informasi kesehatan, meningkatkan pembiayaan kesehatan (Depkes RI, 2006).

Pada Pasal 18 Undang-undang Republik Indonesia No 36 Tahun 2009 tentang kesehatan. disebutkan bahwa Pemerintah bertanggung jawab memberdayakan dan mendorong peran aktif masyarakat dalam segala bentuk upaya kesehatan. Selanjutnya, terkait dengan peran serta masyarakat dituangkan pada pasal; 149 ayat (3) "Pemerintah pusat dan pemerintah daerah bertanggung 
jawab atas pemerataan penyediaan fasilitas pelayanan kesehatan jiwa dengan melibatkan peran serta aktif masyarakat". Pada asal 152 ayat (1) dijelaskan bahwa Pemerintah, pemerintah daerah dan masyarakat bertanggung jawab melakukan upaya pencegahan, pengendalian, dan pemberantasan penyakit menular serta akibat yang ditimbulkannya. Diteruskan pada pasal 155 ayat (3) yang menjelaskan dalam melaksanakan surveilans sebagaimana dimaksud pada ayat (2), pemerintah daerah dapat melakukan kerja sama dengan masyarakat. Terkait dengan peran serta masyarakat dijelaskan pada pada Bab XVI Peran Serta Masyarakat pasal Pasal 174 (1) Masyarakat berperan serta, baik secara perseorangan maupun terorganisasi dalam segala bentuk dan tahapan pembangunan kesehatan dalam rangka membantu mempercepat pencapaian derajat kesehatan masyarakat yang setinggi-tingginya. (2) Peran serta sebagaimana dimaksud pada ayat (1) mencakup keikutsertaan secara aktif dan kreatif.

Ketika melaksanakan program penanganan wabah COVID-19, sudah tentu Pemerintah tidak mungkin bekerja sendiri. Keterlibatan masyarakat sipil dan dukungan dunia usaha swasta sangat dibutuhkan. Sinergi antara pemerintah, masyarakat, dan swasta itulah yang akan membantu mempercepat eksekusi penangangan program-program yang akan memutus mata rantai penyebaran COVID-19. Kombinasi antara kearifan lokal yang terus dipelihara dan dijaga serta strategi kepemimpinan Pemprov Maluku Utara akan mewujudkan upaya dalam melindungi bumi dan tangguh menghadapi bencana.

Menangani masalah kesehatan, tingkat kesejahteraan dan pengurangan kemiskinan sebagai dampak terjadinya penyebaran pandemi Covid-19 dapat dilakukan tidak hanya melalui pemberdayaan ekonomi, namun juga melalui penguatan modal sosial, dan community based development. Penguatan sosial dapat dilakukan dengan mengembangkan skema-skema penguatan modal sosial, seperti peningkatan fungsi BPD, LKMD, Karang Taruna, PKK, BUMDes, dan Koperasi. Penguatan sosial kapital dilakukan dengan memaksimalkan peran lembaga-lembaga sosial dengan memfokuskan pada penguatan aspek kepercayaan, mutual respect, dan mutual benefit, serta memperhatikan faktor budaya dan nilai-nilai yang berlaku.

Community Based Development sebagai mekanisme perencanaan yang menekankan pada teknologi "social learning" dan strategi perumusan program yang bertujuan untuk meningkatkan kemampuan masyarakat mengaktualisasikan diri. Pokok pikiran yang terkandung dalam Community Based Development adalah mencakup: pertama, keputusan dan inisiatif pemenuhan kebutuhan masyarakat setempat dibuat di tingkat lokal oleh warga masyarakat yang memiliki identitas yang diakui peranannya; kedua, memperkuat kemampuan masyarakat miskin mengarahkan dan mengatasi aset-aset yang ada untuk memenuhi kebutuhannya; ketiga, toleransi yang besar terhadap variasi dan karenanya mengakui makna pilihan nilai individual didalam pengambilan 
keputusan dan desentralisasi; keempat, Community based Development menggunakan teknologi "social learning process" dimana individu berinteraksi satu sama lain menembus batas organisatoris dengan mengacu pada kesadaran kritis masing-masing; kelima, Budaya kelembagaan ditandai oleh adanya organisasi otonom, mandiri dan saling berinteraksi memberikan umpan balik; keenam, adanya jaringan koalisi dan komunikasi antara pelaku organisasi lokal yang otonom (Tjokrowinoto, 1996).

Penanganan COVID-19 di Maluku Utara dapat membuahkan hasil yang lebih baik apabila dilakukan melalui metode pentaheliks berbasis kearifan lokal melalui partisipasi masyarakat. Konsep partisipasi masyarakat ini sudah mulai terkikis di tengah wabah pandemi Covid-19. Beban penanganan wabah Covid19 ini banyak tertumpu kepada pemerintah, BUMN maupun swasta, dan sebagian peran masyarakat. Seharusnya, pemerintah mulai memikirkan bagaimana agar partisipasi masyarakat dapat dibangun untuk bersama-sama menangani wabah covid-19. Banyak hal yang bisa diinisiasi untuk membangun partisipasi masyarakat di luar kemampuan pemerintah menangani wabah pandemi covid-19. Dasar penyebaran covid-19 adalah droplet, virus yang dibawa manusia, virus yang melekat pada pakaian yang dipakai manusia (Anonim, 2020).

Kecepatan didalam implementasi kebijakan dengan pendekatan Pembangunan Masyarakat (Community Development) adalah metode pendekatan yang melibatkan masayarakat/komunitas didalam pembangunan. Didalam pembangunan ini melibatkan berbagai unsur-unsur yang lebih luas diantaranya adalah sosial, budaya, ekonomi hingga peraturan/kepranataan dan lingkungan. Sifat dari pendekatan Pembangunan Masyarakat (Community Development) ini adalah proses pembangunan mulai dari tahap idea/gagasan, perencanaan, pembuatan program kegiatan, penyusunan anggaran/biaya, pengadaan sumber-sumber hingga pelaksanaan di lapangan lebih menekankan kepada keinginan atau kebutuhan yang nyata ada (the real needs of community) dalam kelompok masyarakatnya yang bersifat partisipatori.

Dengan demikian penanganan COVID-19 dapat membuahkan hasil yang lebih baik apabila dilakukan melalui metode pentaheliks berbasis kearifan lokal yakni dengan memasukkan unsur peran serta masyarakat. Peran masyarakat inilah yang diharapkan dapat mempercepat pembangunan disegala sektor yang berkaitan dengan pemulihan ketahanan ekonomi nasional. Pemprov Maluku Utara telah berusaha maksimal menangani wabah COVID-19.

Pola hidup masyarakat di Maluku Utara sebagaimana di wilayah lain pun melalui Community Development berbasiskan kearifan lokal sehingga berperan dalam pencegahan kasus COVID-19. Program Community Development memiliki tiga karakter utama yaitu berbasis masyarakat (community based), berbasis sumber daya setempat (local resource based) dan berkelanjutan (sustainable). 
Adapun yang menjadi sasaran dalam program Community Development untuk penanganan Covid19 yaitu kapasitas masyarakat dapat dicapai melalui upaya pemberdayaan (empowerment) agar anggota masyarakat dapat ikut dalam proses produksi atau institusi, kesetaraan (equity) dengan tidak membedakan status dan keahlian, keamanan (security), keberlanjutan (sustainability) dan kerjasama (cooperation), dan semuanya itu diharapkan dapat berjalan secara simultan sehingga tercapai tujuan dari program yang dilakasanakan dengan tepat sasaran serta efektif dalam pelaksanaannya.

Menurut (Pakniany, Imron, \& Degeng, 2020) pemberdayaan masyarakat merupakan upaya melibatkan masyarakat dalam hal pembangunan ekonomi, dikatakan sebagai pembangunan ekonomi karena dalam pelaksanaannya tentu melibatkan keberadaan APBD yang digunakan untuk mempermudah pengadaan kegiatan partisipasi. Dan teori ini memberikan pandangan bahwa peran masyarakat tidak hanya berlangsung dalam aspek permintaan atau pengadaan masyarakat saja, namun banyak hal yang perlu diperhatikan dan sangat penting yang secara langsung dapat memudahkan pelaksanaan kegiatan, salah satu bentuk partisipasi masyarakat adalah dalam pembangunan kebijakan pendidikan, seperti yang dilakukan oleh lembaga pendidikan dan lain sebagainya, (Hughes et al., 2017).

Bentuk peran serta masyarakat yang dilakukan dalam uapaya pencegahan serta penanganan wabah Covid 19 dilakukan berbasis kearifan lokal yang dilaksanakan oleh masyarakat Maluku Utara dengan menggelar upacara keagamaan. Tujuan dilaksanakannya ritual keagamaan tersebut, selain mengucap syukur dan permohonan ampun kepada sang Pencipta, juga agar bencana yang menimpa makhluk di bumi seperti datangnya wabah COVID-19 ini tidak menimbulkan korban lebih banyak lagi.

\section{c. Kearifan lokal Dalam menangani COVID-19 di Provinsi Maluku Utara}

Sebagaimana diketahui dalam pentahelix, kekuatan untuk melawan Covid 19 itu juga datang dari dalam diri masyarakat sendiri. Tersedianya ruang pemberdayaan bagi masyarakat memungkinkan lahirnya kesadaran bersama tentang peran masing-masing pihak sebagaimana terdapat dalam Pentahelix. Memerlukan sinergitas serta keintegrasian didalam pelaksanaan secara simultan program-program penangananserta pencagahan. Pemerintah lakukan tugasnya dan masyarakat juga berbagi perannya. Hanya dengan cara ini, bencana apapun termasuk Covid 19 dapat disikapi, dicegah penularannya dan diobati yang terpapar.

Masyarakat lokal mempunyai kearifan-kearifan lokal. Mereka memiliki sumber daya dan spirit lokal. Ini yang mesti diberdayakan. Kesadaran masyarakat mesti diberdayakan karena sejatinya mereka mempunyai kesadaran. Strategi pentahelix yakni pendekatan yang memprioritaskan penggunaan konteks lokal, kearifan lokal, sumber daya lokal sesuai dengan jiwa gotong royong dalam mencegah dan mengatasi bencana, termasuk pandemi COVID-19. Pendekatan 
kearifan lokal perlu dilakukan karena setiap daerah memiliki ciri khas yang berbeda, ada yang juga diimplementasikan dalam slogan Jaga Torang Pe Diri, Jaga Torang Pe Keluarga, Jaga Torang Pe Daerah.

Provinsi Maluku Utara memiliki karakteristik penduduknya multiagama, sehingga tidak dapat dimungkiri bahwa masyarakatnya masih menjunjung tinggi serta menerapkan kearifan lokal. Yang ada, terutama pendekatan agama. Melalui pendekatan keagamaan, masyarakat Maluku Utara sangat percaya bahwa dengan menjaga alam dengan semestinya, berarti masyarakat atau manusia turut membantu mencegah wabah ini meluas. Oleh sebab itu guna menangani pandemi COVID-19 maka di Maluku Utara dilaksanakan kegiatan terkait kearifan lokal yaitu: ritual tawaf gam (keliling kampung) sambil melantunkan dzikir, juga ada tradisi sigofi gam (membersihkan kampung).

Acara tawaf gam ini melibatkan para tokoh agama, tokoh masyarakat dan pemuda yang dilakukan dengan berjalan secara rombongan. Dalam proses tawaf, mereka berhenti di setiap pertigaan dan perempatan kampung, untuk membacakan doa tolak bala (bencana). Ritual tawaf gam bertujuan untuk mencegah terjadinya bubaku wosa gam atau negeri dilanda wabah. Tradisi ini merupakan kebiasaan yang diturunkan oleh para leluhur di Ternate sejak berabad-abad lalu. Dalam pelaksanaannya, tampak juga anak-anak turut mengiringi dengan membawa obor. Tradisi ini adalah tindakan pencegahan secara spiritual, mengucap syukur serta memohon ampun kita sebagai hamba kepada sang Pencipta (Anonim, 2020).

Disamping dengan kegiatan yang sifatnya religius itu, masyarakat Maluku Utara juga menggunakan kekayaan alam, seperti minyak cendana Kawasan Maluku Utara dikenal sebagai penghasil kayu cendana dengan kualitas yang baik. Dan hasil produk dari kayunya tersebut dapat dipergunakan sebagai aroma terapi bahan dupa juga untuk rempah-rempah. Sebagaimana diketahui, bahwa kualitas kayu yang baik bisa menyimpan aromanya selama berabad-abad. Tanaman cendana mengandung minyak atsiri dan minyak cendana inilah yang dipergunakan oelh masyarakat Maluku Utara untuk mencegah penularan wabah COVID-19 dengan cara dioleskan ke kulit. Masyarakat maluku Utara percaya bahwa imunitas tubuh dapat ditingkatkan melalui aroma wewangian cendana.

\section{d. Ketahanan Nasional}

Persoalan dampak politik dari Covid-19 secara substansial adalah potensi munculnya krisis politik sebagai lanjutan dari gangguan keamanan yang tidak diselesaikan secara menyeluruh atau komprehensif dan berkeadilan. Sejarah di Indonesia memberi pelajaran bagaimana peran elite-elite politik dengan latar belakang organisasi masyarakat (ormas) ataupun sebagai lembaga resmi dari partai politik telah berperan sebagai provokator dan aktor dalam berbagai pergolakan sosial politik di tanah air. Rasa ketidakpuasan sekelompok masyarakat atas kebijakan-kebijakan yang diambil pemerintah dalam penanganan Covid-19 bisa menjadi bibit-bibit ketidakpuasan, kecemburuan 
sosial, perasaan diskriminasi di mata hukum ditambah dengan kesenjangan ekonomi dan kemiskinan yang makin meluas akan sangat mudah ditunggangi oleh agenda-agenda politik.

Wabah Covid-19 juga berpotensi mengancam pertahanan nasional karena dalam situasi semua negara mengalami kekacauan dan kegagalan melawan wabah pandemi Covid-19 maka aspek-aspek pertahanan harus menjadi perhatian serius. Isu-isu geopolitik tidak bisa diabaikan karena pada hari ini sudah tidak ada lagi sekat antar negara, semuanya sangat terbuka. Ketegangan di wilayah Laut China Selatan tentu menjadi alarm bagi sistem pertahanan nasional Indonesia.

Sedangkan dari segi keamanan, sangat jelas bahwa Covid-19 akan berdampak pada terhadap situasi keamanan di lingkungan masyarakat. Hal ini salah satunya terkait dengan tingginya jumlah PHK menyebabkan angka pengangguran semakin melonjak, kesulitan dan himpitan ekonomi akan memicu masalah-masalah sosial di masyarakat termasuk masalah keamanan karena meningkatnya kriminalitas. Berbagai motif tindak kriminalitas yang terjadi dari tidak punya uang untuk makan sampai motif kejahatan dengan kekerasan akan meningkat tajam pada masa pandemi Covid-19. Hal ini tentu menjadi tantangan segenap jajaran penegakan hukum di Indonesia dalam upaya antisipasi supaya potensi tindak-tindak kriminal yang meresahkan masyarakat dan menimbulkan rasa tidak aman dapat ditekan.

Konsep Ketahanan Nasional pada dasarnya mirip konsep keamanan komprehensif, terutama terletak pada sifatnya yang bersifat semesta atau total. Akan tetapi berbeda dengan konsep keamanan komprehensif, konsep Ketahanan Nasional merupakan konsep yang lebih luas cakupannya. Jika Keamanan Komprehensif semata-mata digunakan untuk menghadapi satu benturan fisik dengan luar negeri, maka Ketahanan Nasional di samping digunakan untuk menghadapi agresi dari luar, juga dimaksudkan untuk mengatasi seluruh tantangan, ancaman, hambatan dan gangguan yang dialami satu bangsa dalam memperjuangkan kepentingan nasional dan kelangsungan hidupnya.

Ancaman yang ada di depan mata ialah perlambatan ekonomi global karena sebagian besar negara telah menetapkan pembatasan ruang gerak barang dari luar negeri. Aktivitas ekspor-impor terhenti. Devisa negara menurun. Bencana covid 19 juga sudah pasti membuat neraca keuangan negara-negara di dunia, termasuk Indonesia, berada dalam kondisi tidak sehat. Itu karena sebagian dana harus dialokasikan untuk menghadapi virus mematikan tersebut. Neraca keuangan negara yang mengacu pada RAPBN perlu penyesuaian. Pada momen seperti saat ini, solidaritas seluruh elemen bangsa memang sangat dinantikan. Covid 19 seumpama musuh yang harus dikalahkan secara bersama-sama. Pemerintah harus bekerja sama (bersinergi) dengan elemen organisasi masyarakat sipil, perusahaan, dan masyarakat luas tentang langkah-langkah yang diambil pemerintah untuk dilaksanakan secara bersama. 
Pemerintah perlu berperan sebagai komando yang setiap perintahnya harus diikuti semua elemen bangsa. Tanpa adanya kerja sama, sangat sulit untuk meredam persebaran virus ini. Dalam konteks ketahanan nasional, daya tahan kita sebagai bangsa memang tengah diuji dimulai dari ketangguhan masyarakat dalam menyiapkan kondisi fisik untuk bisa bertahan melawan virus yang rentan menyerang kelompok usia 60 tahun ke atas.

Konfigurasi kekuatan nasional, baik militer maupun nonmiliter, untuk antisipasi kemungkinan-kemungkinan ke depan. Kepatuhan masyarakat untuk melaksanakan imbauan pemerintah tidak keluar rumah selama proses isolasi diri. Solidaritas sesama warga negara ketika berada dalam bencana, apakah citra sebagai bangsa yang gotong royong masih mengakar, karena hal tersebut dapat meningkatkan kerawanan sosial yang berpotensi pada disintegrasi terhadap kondisi dan situasi keamanan dalam negeri.

Undang-Undang Nomor 36 Tahun 2009 telah menguraikan dengan jelas bahwa pembangunan kesehatan merupakan tanggung jawab dari banyak pihak termasuk Pemerintah Pusat melalui Kementerian maupun tanggung jawab dari masing-masing Pemerintah Daerah melalui Dinas Kesehatan dan unit pelaksana teknisnya di lapangan. Namun, tanggung jawab tersebut belum mampu dilaksanakan dengan baik sepenuhnya oleh pemerintah, seperti penyediaan fasilitas, sarana dan prasarana pelayanan kesehatan bagi masyarakat terutama di tingkat desa. Hal ini menyebabkan semakin kompleksnya permasalahan yang dihadapi oleh masyarakat desa

Model Collaborative Governance dalam penanganan wabah Covid-19 di Indonesia yang ideal, integral, paripurna dan sistemik yang mampu menangani wabah Covid-19 dan sekaligus menangani dampak akibat wabah tersebut dalam semua sektor yang berpotensi terdampak. Berdasarkan kebijakan yang dikeluarkan oleh pemerintah daerah dalam merespon meluasnya penyebaran Covid-19, yangmana kejadian ini menimbulkan kekhawatiran yang serius di tengah masyarakat. Ketersediaan fasilitas dan tenaga medis yang terbatas, membuat situasi masyarakat dalam ancaman yang serius di daerah ini.

\section{Kesimpulan}

Pelaksanaaan Community Development sebagai upaya implementasi kebijakan untuk ketahanan nasional sebagai dampak wabah covid 19 yang dilakukan secara terintegrasi ini akan menghasilkan kapasitas adaptasi, antara lain berupa: kerja sama, partisipasi semua elemen masyarakat, prinsip saling menjaga, pemanfaatan teknologi yang sesuai kebutuhan masyarakat, dan kemampuan memobilisasi sumber daya kolektif dalam anggota kelompok. Bentuk-bentuk kapasitas adaptasi yang dikembangkan adalah sebuah daya lenting dan fleksibilitas untuk menjaga stabilitas pembangunan dan pengelolaan infratsruktur-infrasrtuktur pendukung didalam menangani serta pencegahan penyebaran covid 19. 
Dilain pihak pemberdayaan masyarakat merupakan upaya melibatkan masyarakat dalam hal pembangunan ketahanan ekonomi dikatakan sebagai pembangunan ekonomi karena dalam pelaksanaannya tentu melibatkan keberadaan APBD yang digunakan untuk mempermudah pengadaan kegiatan partisipasi. Hal tersebut terlihat bahwa peran masyarakat tidak hanya berlangsung dalam aspek permintaan atau pengadaan masyarakat saja, namun banyak hal yang perlu diperhatikan dan sangat penting yang secara langsung dapat memudahkan pelaksanaan kegiatan, salah satu bentuk partisipasi masyarakat adalah dalam pembangunan daerah serta perencanaan maupun implementasi kebijakan pendukungnya.

Strategi kepemimpinan juga kearifan lokal menjadi kunci penting bagi Pemprov Maluku Utara dalam memerangi wabah COVID-19 ini. Pemprov Maluku Utara tidak berhenti mencari strategi yang inovatif dan progresif. Hingga saat ini Pemprov tetap mengacu pada tiga indikator keberhasilan penanganan COVID-19. Pertama, menekan laju pertambahan kasus positif. Kedua, meningkatkan angka kesembuhan, dan ketiga, menekan angka pasien wafat. Dengan memahami akan banyaknya masyarakat berisiko tinggi dan rentan terhadap COVID-19, Pemprov Maluku Utara memberi perhatian khusus terhadap kelompok masyarakat berisiko tinggi dengan meningkatkan perlindungan dan pencegahan penularan pada masyarakat. Upaya-upaya yang dilakukan dimulai dengan pendataan warga dengan profil risiko tinggi terpapar COVID-19, monitoring Orang Tanpa Gejala (OTG), Orang dalam pemantauan (ODP) terutama ODP yang berisiko tinggi seperti balita dan lansia (warga diatas 60 tahun) serta Pasien dalam Pengawasan (PDP) dengan gejala ringan yang melakukan isolasi mandiri di rumah. 
Startegi Implementasi Kebijakan Penanganan COVID-19 untuk Ketahanan Nasional Berbasis Community Development (Konsep Pentahelix)

\section{BIBLIOGRAFI}

Anonim. (2020). Pengalaman Indonesia Dalam Menangani Wabah COVID-19. Jakarta: Universitas Indonesia Dan BNPB.

Calzada, Igor. (2016). (Un)Plugging Smart Cities With Urban Transformations: Towards Multi-Stakeholder City-Regional Complex Urbanity? URBS. Revista de Estudios Urbanos y Ciencias Sociales, 6(2), 25-45.

Carayannis, Elias G., \& Campbell, David F. J. (2010). Triple helix, Quadruple helix and Quintuple helix and how do Knowledge, Innovation and the Environment relate to Each other? a proposed framework for a trans-disciplinary analysis of sustainable development and social ecology. International Journal of Social Ecology and Sustainable Development, 1(1), 41-69.

Carrillo-Larco, Rodrigo M., \& Castillo-Cara, Manuel. (2020). Using country-level variables to classify countries according to the number of confirmed COVID-19 cases: An unsupervised machine learning approach. Wellcome Open Research, 5.

Eifert, Laszlo, Banerjee, Rupak, Jusys, Zenonas, \& Zeis, Roswitha. (2018). Characterization of carbon felt electrodes for vanadium redox flow batteries: Impact of treatment methods. Journal of The Electrochemical Society, 165(11), A2577.

Gates, Paul W. (2017). The Farmer's Age: Agriculture, 1815-60: Agriculture, 1815-60. Routledge.

Halibas, Alrence Santiago, Sibayan, Rowena Ocier, \& Maata, Rolou Lyn Rodriguez. (2017). The Penta Helix Model of Innovation in Oman: An HEI Perspective. Interdisciplinary Journal of Information, Knowledge, and Management, 12, 159172.

Hastuti, Puji, Nurofik, Agus, Purnomo, Agung, Hasibuan, Abdurrozzaq, Aribowo, Handy, Faried, Annisa Ilmi, Tasnim, Tasnim, Sudarso, Andriasan, Soetijono, Irwan Kurniawan, \& Saputra, Didin Hadi. (2020). Kewirausahaan dan UMKM. Sumatera Utara: Yayasan Kita Menulis.

Hendriyana, Husen, Putra, I. Nyoman Darma, \& yan Sunarya, Yan. (2020). Industri Kreatif Unggulan Produk Kriya Pandan Mendukung Kawasan Ekowisata Pangandaran, Jawa Barat. Jurnal Panggung. Vol. 30. N0, 2.

Hughes, Terry P., Kerry, James T., Álvarez-Noriega, Mariana, Álvarez-Romero, Jorge G., Anderson, Kristen D., Baird, Andrew H., Babcock, Russell C., Beger, Maria, Bellwood, David R., \& Berkelmans, Ray. (2017). Global warming and recurrent mass bleaching of corals. Nature, 543(7645), 373-377.

Liu, Songqiao, Luo, Huanyuan, Wang, Yuancheng, Wang, Duolao, Ju, Shenghong, \& Yang, Yi. (2020). Characteristics and associations with severity in COVID-19 
Ali Ibrahim dan Henny Saptatia Drajati Nugrahani

patients: a multicentre cohort study from Jiangsu Province, China. China $(2 / 28 / 2020)$.

Pakniany, Nova Suci Lestari, Imron, Ali, \& Degeng, I. Nyoman Sudana. (2020). Peran Serta Masyarakat Dalam Penyelenggaraan Pendidikan. Jurnal Pendidikan: Teori, Penelitian, dan Pengembangan, 5(3), 271-278.

Rudi Natamiharja, Rudi Natamiharja. (2020). Keberkahan Virus Corona dalam Peningkatan Hak Dasar Atas Kesejahteraaan Masyarakat Indonesia. In: Corona Guru Kita: Belajar Berempati. Bandar Lampung: Aura Publishing, pp. 139-144

Statistik, Badan Pusat. (2020). Pencegahan Perkawinan Anak. Jakarta: Kementerian Perencanaan Pembangunan Nasional.

Sudiana, Kiki, Sule, Erni Tisnawati, Soemaryani, Imas, \& Yunizar, Yunizar. (2020). The development and validation of the penta helix construct. Business: Theory and Practice, 21(1), 136-145.

Suharsono, Agus. (2020). Penggunaan Aplikasi Quizizz dalam Pelatihan Dasar CPNS KEMENKEU Generasi Milenial. Jurnal Kajian, Penelitian dan Pengembangan Kepribadian, 11(1), 60-66.

Tjokrowinoto, Moeljarto. (1996). Budaya birokrasi dalam konteks transformasistruktural: antara harapan dan kenyataan. Jurnal Kebijakan Dan Administrasi Publik. 